http://dx.doi.org/10.12775/szhf.2017.008

\title{
Husserlowska eksplikacja jako wyższa forma intuicyjnej metody fenomenologicznego oglądu
}

\section{Wstęp}

Eksplikacja jest zagadnieniem szczegółowo poruszanym przez Husserla w Doświadczeniu i sądzie. Na kartach żadnego innego ze swoich dzieł nie poświęcił jej tyle miejsca. Jako metoda oglądowa ściśle wiąże się z problematyką intuicji. Tej drugiej Husserl nie szczędził jednak pióra. Intuicja, rozumiana jako bezpośredni ogląd przedmiotu przedstawienia, stanowi obok takich kategorii, jak intencjonalność czy czysta świadomość, fundamenty prawomocności poznania i doświadczenia przedmiotu w jego cielesnej samoobecności. I od refleksji nad nią rozpocznę rozważania, aby później przejść do szczegółowej analizy eksplikacji jako metody dotarcia do bezpośrednich danych przedmiotu doświadczenia, której Husserl przeciwstawił świadomość horyzontową. 


\section{Intuicja}

Jak wyżej zostało nakreślone, intuicja w najprostszym jej ujęciu to bezpośredni ogląd przedmiotu. Już w przedtranscendentalnych Badaniach logicznych twórca fenomenologii pisze o naoczności uobecniającej, ściśle łącząc ją z kategorią „wypełnienia”. Wypełnienie odwołuje się do relacji: intencja (sygnitywna) - intuicja. Intencja (sygnitywna) stanowi pewnego rodzaju przeżycie, w którym coś pomyślanego nie jest dane w bezpośredniej naoczności, a więc w intuicji. Husserl w Badaniach podaje dwa rodzaje wypełnienia mówi o wypełnieniu statycznym i dynamicznym. Dość łatwo scharakteryzować te dwa rodzaje wypełnienia, jeśli w wyjściowym kroku oprzemy się na podziale intencji na czysto sygnitywną (znaczeniową) oraz właśnie intencję intuicyjną. W statycznym wypełnieniu mamy do czynienia $\mathrm{z}$ „biernym” rozpoznaniem przedmiotu poznania, który jest nam naocznie dany - po prostu „widzimy przed sobą" jakiś obiekt w trakcie np. mówienia o nim. Zatem zachodzi tutaj, jak mówi Husserl, statyczna jedność między aktami naoczności a aktami wyrażającymi. W drugim tomie Badań czytamy:

Np. mówię o moim kałamarzu [...]. Nazwa nazywa przedmiot spostrzeżenia i nazywa go za pośrednictwem znaczącego aktu [...]. Stosunek zachodzący między nazwą i tym, co nazwane wykazuje w tym stanie jedności pewien charakter opis owy [...]: nazwa mój kałamarz niejako "nakłada się" na spostrzeżony przedmiot, by tak rzec, $\mathrm{n}$ a m a caln i e należy do niego ${ }^{1}$.

Pojawia się pytanie, co stanowi kryterium jedności intencji znaczeniowych $\mathrm{z}$ aktami naoczności? Dane przeżycia aktowe wyposażone są w swoiste zapośredniczone odniesienie. Jest ono odniesieniem, które za pomocą na zywania nie tylko opiera się i czerpie z określonej puli znaczeń, lecz także - w myśl tej określoności - rozpoznaj e dany przedmiot, ustawia go w ramach „namierzonej” klasyfikacji. Tutaj akt klasyfikujący, będący identyfikatorem przedmiotu spostrzeżenia, $w$ istocie sprzężony jest $\mathrm{z}$ aktem spostrzeżenia i uprzednio także ze znaczącym wyrażeniem. Jak pisze Husserl:

wyrażenie jawi się jako nałożone na rzecz jako szata [...]. To, że akty sygnifikacji [akty intencji znaczeniowej, znaczenia - M. G.] i intuicji mogą wchodzić $\mathrm{w}$ ten jedyny w swoim rodzaju stosunek, to pierwotny fakt fenomenologiczny.

${ }^{1}$ E. Husserl, Badania logiczne, t. 2, cz. 2, przeł. J. Sidorek, Warszawa 2000, s. 34. 
I tam, gdzie to czynią, gdzie w danym przypadku akt intencji znaczeniowej wypełnia się w intuicji, tam mówimy też, że „przedmiot naoczności został rozpoznany przez swe pojęcie" $[\ldots]^{2}$.

Natomiast w przypadku wypełnienia dynamicznego występuje, zdaniem Husserla, zróżnicowanie czasowe. Akt poznawczy i odpowiadające mu człony wypełnieniowe poddane są przekształceniom, następuje ich temporalny rozwój w odróżnieniu od stosunku statycznego, w którym wypełnienie intencji poprzez intuicje nie ulega czasowemu kształtowaniu, lecz jest „byciem wypełnionym, [...], pozostawaniem w stanie pokrywania się"3. W statycznym wypełnieniu przedmiotowe domniemanie oraz wypełniająca się naoczność zbiegają się w aspekcie przedmiotowo-czasowym. Z kolei, jak pisze A. Półtawski w książce Świat. Spostrzeżenie. Świadomość, interpretując kontekst rzeczowo-czasowy wypełnienia w relacji dynamicznej: „rozgrywa się ono jako pewien proces $\mathrm{w}$ czasie. $\mathrm{Z}$ przedmiotowego punktu widzenia $\mathrm{w}$ akcie wypełnienia pojawia się identyczność przedmiotu obu intencji; wypełnienie i poznanie są aktami identyfikującymi”"

Zarówno akty wypełnienia, jak i akty znaczeniowe, są aktami posiadającymi moc uprzedmiotawiającą. Z istoty stanowią akty nadające sens. Husserl mówi o poznawczej identyfikacji, w której akty w drodze syntetycznego zbiegu, stanowiąc ,jedność”, opierają się na wypełnieniowych przeżyciach. Dany akt intuicyjny stanowi konstrukt wypełnieniowy dla sygnifikatywnych przeżyć, cechujących się intencjonalnością. Pusta intencja niejako celuje $\mathrm{w}$ „namierzoną” przez siebie naoczność . Pisząc o syntezie wypełnienia jako o syntezie identyfikującej, Husserl wiąże ją ściśle z rodzajowym charakterem intencji. Równolegle do podziału klasowego aktów obiektywizujących dokonuje rozróżnienia na dwa rodzaje obiektywizujących intencji: sygnitywne - będące znaczeniami wyrażeń, które znajdują podłoże w zmysłowym użyciu wyrażeń, w naoczności, lecz bez aspektu treściowego; intuicyjne w tym imaginacyjne (obrazowe - wypełnienie imaginacyjne następuje drogą syntezy podobieństwa) oraz spostrzeżeniowe (Husserl pisze w tym miejscu o syntezie identyczności rzeczy: mimo, że przedmiot ukazuje się

\footnotetext{
2 Tamże, s. 35, 44-45.

${ }^{3}$ Tamże, s. 45.

${ }^{4}$ A. Półtawski, Świat. Spostrzeżenie. Świadomość, Warszawa 1973, s. 58.

${ }^{5}$ Tamże, s. 60.
} 
w różnych aspektach, stronach, to jednak pozostaje tym samym przedmiotem spostrzeżenia) ${ }^{6}$.

Idąc dalej, skoncentrujmy się na analizie spostrzeżenia zmysłowego, ponieważ wokół niego będą potem oscylowały rozważania dotyczące eksplikacji. Spostrzeżenie tego rodzaju, jak twierdzi Husserl w Badaniach logicznych, "pretenduje i do tego, że w ogóle nie jest ono samą tylko intencją, lecz aktem, który może dostarczyć innym aktom wypełnienia, sam jednak żadnego wypełnienia już nie potrzebuje. Zazwyczaj [...] kończy się to na tej pretensji”’. Jak twierdzi filozof, pretensje te nie mogą zostać zaspokojone, ponieważ przedmiot takiego spostrzeżenia zmysłowego nie przejawia się w całkowitej swej odsłonie, lecz jedynie poprzez wyglądy. Podczas spostrzeżenia danego przedmiotu nieosiągalne dla naszego wzroku strony przedmiotu są współdomniemane wespół $\mathrm{z}$ widocznymi dla nas jego częściami. Te widoczne elementy obiektu stanowią, jako pierwszorzędne treści, reprezentanty tego, co wykracza poza to, co dane naocznie. Nie stanowią one ani imaginacyjnej, obrazowej danej spostrzeżenia, ani nie należą do jego percepcyjnej zwartości. Taki rodzaj epistemicznego dostępu do przedmiotu poznania nasuwa konstatację, że spostrzegając określony obiekt, może on wyposażać ujęcie w rozmaite treści, a samoprezentacja może być stopniowalna; do tego identyfikacja przedmiotu może odsyłać do unaocznienia na różnym poziomie doskonałości. Husserl pisze: „Gdyby spostrzeżenie zawsze było tym, do czego pretenduje, [mianowicie] rzeczywistą i rzetelną samoprezentacją przedmiotu, [...] dla każdego przedmiotu istniałoby tylko jedno jedyne spostrzeżenie"8.

Uważam, że powyższe rozważania są dobrym asumptem, by wykroczyć poza przedtranscendentalne rozważania i połączyć je z tymi, które dały podwaliny do głównych założeń transcendentalnej metody fenomenologicznej. Dlatego też w następnej części artykułu przyjrzę się intuicji pod kątem adekwatności i apodyktyczności spostrzeżenia, poddając analizie najpierw to, co Husserl sądził na ten temat w Badaniach logicznych, po czym przejdę do rozważań zawartych w dziełach po nich następujących.

Dariusz Łukasiewicz w pozycji Sąd i poznanie w fenomenologii Edmunda Husserla podaje za Husserlem trzy typy intuicji: retrospekcyjną (jej przedmiot stanowią podmiotowe przeżycia); zmysłową (ta za przedmiot oglądu obiera rzeczy) oraz ejdetyczną (odnosi się do eidos, czyli do istot ogólnych).

\footnotetext{
${ }^{6}$ E. Husserl, Badania logiczne, s. 70.

7 Tamże.

${ }^{8}$ Tamże, s. 71.
} 
Warto podkreślić, że ostatni z wymienionych rodzajów intuicji może przybierać odmianę immanentną lub transcendentną, w zależności od statusu ontologicznego przedmiotu poznania.

Należy zaznaczyć, że eidos jest terminem używanym przez Husserla w późniejszym okresie twórczości. W Badaniach logicznych na określenie istoty ogólnej obowiązuje termin species. Oba terminy (species i istota) są równozakresowe i można ich używać zamiennie?.

Aby przyjrzeć się bliżej Husserlowskim terminom „apodyktyczny” i „adekwatny", zwróćmy najpierw uwagę, co twórca fenomenologii rozumiał pod pojęciami oczywistości (Evidenz) i prawdy. Pamiętamy, w myśl wcześniejszych rozważań, że koniecznymi elementami relacji wypełnienia są intencja i intuicja. W odniesieniu do prawdy Husserl mówi o konieczności ich zupełnej „zgodności”. W najprostszym ujęciu chodzi o pełne pokrycie się przedmiotu myśli z tym, co dane nam w naoczności. Nie trudno doszukać się tutaj odniesienia do klasycznej definicji prawdy Arystotelesa ${ }^{10}$.

Czym jest dyskusyjne od tysięcy lat filozoficzne pojęcie prawdy, próbuje następująco przybliżyć w Badaniach logicznych Husserl: „p r a w d a jako korelat aktu identyfikującego jest pewnym stanem rzeczy, a jako korelat pokrywającejidentyfikacji jest identycznością: pełną zgodnością zachodzącą pomiędzy tym, co domniemane a tym, co dane jako takim"11.

W dalszej części tekstu Badań Husserl charakteryzuje oczywistość jako przeżycie prawdy. Drogą przechodniości możemy wysunąć wniosek, że oczywistość jest przeżyciem zupełnej zgodności intencji z intuicją. Jednak w przypadku określenia oczywistości jako przeżycia prawdy, należy wykazać się pewną ostrożnością. Rodzi to niebezpieczeństwo utożsamiania oczywistości z szeroko pojmowanym spostrzeżeniem prawdy. Nie można bowiem utożsamiać ze sobą dwóch okoliczności: zachodzenia identyfikującego pokrywania i spostrzegającego stwierdzenia przedmiotowej zgodności w aktualnej treści. Ta druga zachodzi niejako „poza”, w osobnym akcie obiektywizacji. Prawda, która jawi się nam w aktualności, ujmowana jest w innego rodzaju spostrzeżeniu. Husserl pisze, że „a priori zachodzi tutaj możliwość, by w każdej chwili

\footnotetext{
${ }^{9}$ D. Łukasiewicz, Sąd i poznanie w fenomenologii Edmunda Husserla, Bydgoszcz 2008, s. $135-136$.

10 Tamże, s. 137.

${ }^{11}$ E. Husserl, Badania logiczne, s. 146.
} 
spojrzeć na zgodność i w adekwatnym spostrzeżeniu doprowadzić do jej intencjonalnego uświadomienia sobie" ${ }^{12}$.

W zacytowanym fragmencie Badań pojawia się termin adekwatności, któremu przyjrzymy się nieco bliżej. Nasuwają się zatem pytania: kiedy mówimy o adekwatności spostrzeżenia? W jakich przypadkach mamy do czynienia $\mathrm{z}$ intuicją adekwatną? W rozumieniu Husserla określenie adekwatny oznacza zupełny. Spostrzeżenie jest adekwatne, kiedy przedmiot poznania ujęty jest treściowo we wszystkich swoich określeniach. I taka również teoria adekwacji pojawia się w późniejszym dziele Husserla, mianowicie w Medytacjach kartezjańskich, gdzie pisze on o idei oczywistości adekwatnej. W par. 5. tego dzieła przedstawia najpierw swoją koncepcję oczywistości - w mojej ocenie dużo dojrzalszą i bardziej „ufilozoficznioną” niż ta z okresu Badań. Oczywistość stanowi pewnego rodzaju doświadczenie, które jest duchowym unaocznieniem sobie przedmiotu poznania. Owo „coś” jawi się nam we własnej, cielesnej samoobecności. Ta cielesność ma jednak inny wymiar niż czysto materialny. Dochodząc do istoty tego, co poznajemy, doświadczamy także charakteru jego istnienia („von Seiendem zu So-Seiendem”). Skoro wspomniane zostało wcześniej, że oczywistość stanowi przeżycie prawdy, to czym w takim razie będzie jej negacja? Ta wyraża się w ,niezgodności z tym, co ona ukazuje, z tym, co uwidacznia doświadczenie, [...] wyrażającą się w sądzie jako pozytywna oczywistość nie-istnienia rzeczy. [...] ma za swą treść oczywistą fałszywość"13. W takim razie jej przeciwieństwo, przeciwieństwo oczywistej fałszywości, będzie stanowiła doskonała oczywistość, a wraz z nią prawda w całej swojej autentyczności. Husserl nazywa je ideami immanentnymi, które stanowią zasób epistemicznego pociągu do poznania i dążą do wypełnienia intencjonalnych domniemań.

Przechodząc już bliżej do określenia idei adekwatnej oczywistości, zastanówmy się najpierw, czym, ściśle i fenomenologicznie charakteryzując, jest niedoskonałość oczywistości? Jak twierdzi niemiecki fenomenolog, jest ona niejaką jednostronnością, czymś niejasnym i niewyraźnym. Rzeczy w niej się przejawiające prezentują się niezupełnie. Wszelkie domniemanie przedmiotów doświadczenia $\mathrm{w}$ tym aspekcie stanowią niewypełnione w naoczności antycypacje. Oczywistość adekwatna zakłada tutaj pewien stopień doskonałości. Nieodzowne staje się pytanie, czy podobna go osiągnąć w całości, czy jest to jedynie permanentny proces, w którym zespół domniemań osiąga sto-

\footnotetext{
${ }^{12}$ Tamże.

${ }^{13}$ E. Husserl, Medytacje kartezjańskie, przeł. A. Wajs, Warszawa 1982, s. 16.
} 
pień wypełnienia w naoczności? Husserl odpowiada twierdząco na tę drugą opcję. Jednocześnie przyznaje moc obowiązującą ciągowi syntez, które stanowią zespolenie przebiegających jednozgodnie doświadczeń ${ }^{14}$.

Nakreślając, czym jest spostrzeżenie adekwatne, stanowiące $\mathrm{w}$ istocie zupełną prezentację przedmiotu $\mathrm{w}$ jego bezpośrednim oglądzie, nie można pominąć rozważań dotyczących oczywistości apodyktycznej. Apodyktyczny $\mathrm{w}$ terminologii Husserla znaczy absolutnie niepowatpiewalny. Husserl w Medytacjach pisze o absolutnej pewności, przyznając oczywistości apodyktycznej większą ważność niż oczywistości adekwatnej. Adekwatność nie jest żadnym gwarantem pewności poznania, gdyż dane spostrzeżenie może być „niezupełne”, lecz cechować się apodyktycznością. Twierdzenie na temat koekstensjonalności obu pojęć ewoluowało w koncepcjach fenomenologa. Początkowo w Badaniach logicznych, i później w bardziej zdecydowany sposób w Ideach I, przyznaje obu predykatom wymiar równozakresowości. Z tego wynika, że jeśli spostrzeżenia zewnętrzne i wewnętrzne (odpowiednio intuicja zmysłowa i introspekcyjna) są nieadekwatne, to są także powątpiewalne, nieapodyktyczne ${ }^{15}$.

Jednak w ostatnim okresie twórczości, chodzi tu głównie o Medytacje, Husserl, posługując się transcendentalnym doświadczeniem Ja jako ego cogito, występuje wbrew dotychczasowemu założeniu o równozakresowości obu terminów, i sądzi, że:

adekwatność i apodyktyczność oczywistości nie muszą iść z sobą w parze. [...] W doświadczeniu tym ego dostępne jest sobie samemu w sposób pierwotny. Ale to, co właściwie adekwatnie doświadczane, stanowi zaledwie rdzeń tego doświadczenia - jest nim mianowicie żywa teraźniejszość czystego Ja (Selbstgegenwart), którą wyraża sens twierdzenia ego cogito, gdy tymczasem poza tą sferą rozpościera się jedynie [...] w charakterze czegoś presumptywnego horyzont tego, co w sposób właściwy niedoświadczane, [...] choć z koniecznością współdomniemywane ${ }^{16}$.

Do horyzontu tego należą także własności habitualne ego, jako jego trwałe przekonania, jak i całe jego uposażenie transcendentalne wraz z przeszłościowym bagażem dotychczasowych doświadczeń. Ten bliżej nieokreślony horyzont dotyka także problematyki oczywistości apodyktycznej, jeśli idzie

\footnotetext{
${ }^{14}$ Tamże, s. 21.

${ }^{15}$ D. Łukasiewicz, Sąd i poznanie..., s. 138.

${ }^{16}$ E. Husserl, Medytacje kartezjańskie, s. 32.
} 
o doświadczenie transcendentalnego Ja. Husserl tłumaczy, że „rzeczywistość pierwszej w sobie podstawy poznania jest [...] wprawdzie absolutnie pewna"17. Co zatem sprawia trudność? Nie mamy absolutnej pewności, będąc apodyktycznie pewnymi istnienia owego Ja jestem, co tak naprawdę stanowi kryterium stanowiące wyznacznik jego rzeczywistego bytu, a dokładniej chodzi o to, „co w fazie rozpościerania się żywej oczywistości [...] nie jest jeszcze samo dane, lecz tylko $\mathrm{z}$ charakterem presumpcji antycypowane (präsumiert)" ${ }^{18}$. Zatem pojawia nam się pewnego rodzaju dualizm samopoznania: $\mathrm{z}$ jednej strony wszelkie zasoby, jakimi dysponuje transcendentalne Ja, jako ego cogito, cechują się apodyktycznością; ale z drugiej strony, jak sugeruje podchwytliwie i sam Husserl - w kontekście ryzykownego założenia o niepowątpiewalności ego, Ja może ulegać fałszywym przekonaniom, jednocześnie będąc „ofiarą" własnych, niesłusznych, współimplikowanych antycypujących domniemań.

Jak łatwo zauważyć, wszelkie rozważania na gruncie kategorii intuicji związane są bezdyskusyjnie z problemem konstytucji. Kontekst ten jest gwarantem fenomenologicznego przebiegu doświadczenia. Ontologia, inaczej rozumiana niż ta osiemnastowieczna, której podstawy zakorzenione były jedynie $\mathrm{w}$ pojęciach, a nie $\mathrm{w}$ rzeczach samych, ma swoje aprioryczne założenia. Założenia te z konieczności muszą być objęte związkiem koniecznym z bezpośrednim oglądem, z wypełnieniem w naoczności. Konstytutywne odsłonięcie struktur noetyczno-noematycznych musi opierać się na transcendentalno-fenomenologicznych procesach konstytucji, przebiegających w czystej, źródłowej świadomości. Jak pisze Husserl w Medytacjach kartezjańskich, znów zataczając koło, idzie tu o postępowanie czerpiące z czystej intuicji, w celu jak najbardziej precyzyjnego wydobycia sensu w oczywistości. Są to rozważania sięgające najwyższej rangi, w końcu dotyczą sposobu poznawania świata nas otaczającego, świata przedmiotów realnych, czy też świata idealnych bytów. Rzetelność przebiegu operacji wydobycia sensu nie ma na celu zmiany tego sensu, który posiada rzeczywistość w przedfilozoficznym nastawieniu. Raczej chodzi o „wydobywanie sensu, który świat ten posiada dla nas wszystkich, jeszcze zanim zaczynamy w jakikolwiek sposób filozofować, [...] wydobywa ona sens [fenomenologia - M. G.], który może być filozoficznie odsłonięty,

\footnotetext{
17 Tamże, s. 33.

18 Tamże.
} 
ale nigdy nie zmieniony, [...] jako sens otoczony wymagającymi zasadniczego rozjaśnienia horyzontami” 19 .

\section{Eksplikacja}

Po zaznajomieniu się z powyższymi wywodami dużo łatwiej będzie nam zrozumieć dość trudne rozważania zawarte w Doświadczeniu i sądzie na temat eksplikacji jako formie doświadczenia, która stanowi przedpredykatywne stadium doświadczenia predykatywnego.

Doświadczenie przedpredykatywne rozumiane jest przez Husserla jako doświadczenie odbiorcze. Twórcę fenomenologii interesowało przede wszystkim to, w jakich sposób syntezy predykatywne nadbudowują się nad przedpredykatywnymi, analizując formy spostrzeżenia zewnętrznego, jako ujmowania przedmiotów bytujących w czasie i przestrzeni. Podkreśla on jednak przy tym, że poddanie analizie akurat zewnętrznej formy oglądu stanowi jedynie egzemplifikację rozważań, a nie zarezerwowaną dla nich wyłączność, gdyż takie obszary świadomości, jak pole biernych przeddań, struktury odbiorczości, samorzutności, aktywne zwracanie się ja ku... obejmują pola świadomości wykraczające poza zewnętrzne doświadczenie i obszar doksa. Fenomenolog mówi o pewnego rodzaju pierwotnej bierności, która obejmuje sferę zmysłowej odbiorczości. W spostrzeżeniu dane są nam pobudzające, "zachęcające" nas do obserwacji i poznania obiekty. Jednak nie idzie tutaj o pojedyncze, oderwane od reszty otaczających je stanów i rzeczy przedmioty, lecz o całe pole przeddania. Jak czytamy w Doświadczeniu i sq̨dzie: „Spostrzeganie, [...] oglądanie ich i eksplikacja [przedmiotów - M. G.], jest już aktywnym dokonaniem ja. [...] zakładamy tylko, że jest pewne pole wyodrębnień dla mnie, na które orientuje się moje spostrzeganie" ${ }^{20}$.

Wypada poczynić kilka uwag i dokonać krótkiej charakterystyki owego pola, które posiada asocjacyjną strukturę. Jak sądzi Husserl, pole biernych przeddań nie jest miejscem kształtowania się przedmiotowości, ponieważ ten szczebel poznania dokonuje się na wyższym poziomie i przebiega w postaci sądu predykatywnego. Nie ujmuje to jednak ważności tej strukturze świadomości. Jest ona bazą dla dalszych przebiegów świadomościowych i wbrew

\footnotetext{
19 Tamże, s. 208, 227.

${ }^{20}$ E. Husserl, Doświadczenia i sq̨d, przeł. B. Baran, Warszawa 2013, s. 78.
} 
pozorom nie stanowi li tylko mieszaniny nieuporządkowanej mnogości danych. Do pola biernych przeddań należą ściśle określone warstwy, na które składają się rozmaite złożoności i wyodrębnienia z całości. Opierając się chociażby na przykładzie pola zmysłowego, złożonego z barw przyporządkowanych danym obiektom - ono samo nie stanowi jeszcze ukonstytuowanego przedmiotu poznania, lecz, zdaniem Husserla, „w każdej chwili można odpowiednio skierować spojrzenie i uczynić przedmiotem same te apercepcyjne podwarstwy. [...] dane zmysłowe do abstrakcyjnego wydobycia same są już jednostkami tożsamości, [...] które potem [...] mogą same stać się tematycznie ujętymi przedmiotami; widzenie-teraz białej barwy [...] nie jest jeszcze samą białą barwą"21. Należy zatem wnioskować, że same dane zmysłowe nie są nam dane w spostrzeżeniu tak po prostu, lecz stanowią pewnego rodzaju wytwór dokonań konstytutywnych. Podstawowym ich etapem jest konstytucja wewnętrznej świadomości czasu i jej syntetyczne operacje, które mają za zadanie nadawać w wymiarze ogólności tożsamość temu, co dane w intuicyjnym oglądzie, w którym z kolei eksplikacja stanowi spostrzeżeniową tendencję. Dlaczego konstytucja wewnętrznej świadomości czasu koordynuje w najniższych strukturach przebieg spostrzeżenia? Husserl odpowiada, iż dlatego, że „wprowadza formę uniwersalnego porządku i następstwa i formę współistnienia wszelkich immanentnych daności. [...] Trwająca immanentna dana trwa tylko jako dana swej treści. Tak oto syntezy wytwarzające jednię pola sensu są już [...] wyższym piętrem dokonań konstytutywnych"22.

Powiedzieliśmy na początku wywodów odnoszących się do pola biernych przeddań, że przynależą do niego asocjacyjne struktury. Te przebiegają na wyższym szczeblu dokonań konstytutywnych i łączą się z jednią homogeniczności pola sensu. Każde pole sensu stanowi jedność samą dla siebie, a w odniesieniu do innych pól pozostaje w heteronomicznej relacji. Husserl twierdzi, że owa jedność powstaje na zasadzie kontrastu, gdy np. na podłożu jakiegoś przedmiotu o określonym kolorze widoczne są plamy innego koloru. Zachodzi tutaj jednocześnie, mimo kontrastującego charakteru, związek pokrewieństwa (obie barwy stanowią zmysłowe dane - w tym przypadku wzrokowe) oraz stapiania się (plamy tego samego koloru traktowane są jako zamienne; w innym miejscu Husserl nazywa stapianie ścisłym przyleganiem). Dlatego też fenomenologicznie uzasadnione jest pytanie, w jaki sposób rodzi się świadomość, w której dokonuje się identyfikacja na zasadzie podobień-

\footnotetext{
${ }^{21}$ Tamże, s. 78.

${ }^{22}$ Tamże, s. 78-79.
} 
stwa lub jednakowości; a odpowiedź na nie nasuwa szereg fenomenologicznych możliwości badawczych, które przynoszą istotne antypsychologistyczne konstatacje.

Bez wątpienia jasna jest różnica pomiędzy danymi wzrokowymi a dźwiękowymi i zachodząca tutaj heteronomiczność. Co warte dalszego podkreślenia odnośnie do relacji podobieństwa - „podobieństwo pojedynczych danych nie tworzy żadnego realnego związku"23. Oczywiście możemy tak mówić na poziomie własności realnego przedmiotu. W immanentnej teraźniejszości interesuje nas „sposób immanentnego powiązania danych wrażeniowych"24.

Biorąc pod uwagę relację podobieństwa, należy stwierdzić, że posiada ono różne poziomy - jego szczytowym momentem może być jednakowość nie posiadająca odstępów. Husserl pisze o odznaczającym się najwyższą doskonałością pokrewieństwie. To, co jawi się nam jedynie jako podobne, jest efektem specjalnego rodzaju syntezy, zwanej przez Husserla syntezą pokryciową. „Także przy przejściu od podobnego do podobnego występuje [...] pokrywanie się, ale tylko częściowe i wraz z opozycją niejednakowego" ${ }^{25}$. Fenomenolog syntezę tej kategorii nazywa właśnie asocjacją, nadając jej nieco inny sens niż czynił to we wcześniejszych wywodach. U asocjacyjnego podłoża leży, rzecz jasna, konstytucja wewnętrznej świadomości czasu. Asocjacja, która przebiega przez pole biernych przeddań, stanowi fenomen tegoż pola, przynależny genezie skojarzeniowej i stanowiący kolejny szczebel poznania. Określona jest jako istotowa forma prawidła immanentnej genezy. Sfera immanencji odgrywa tutaj znaczącą rolę i wyznaje niejako zasadę: „coś przypomina coś”. Każda forma skojarzeniowa odwołuje się do relacji podobieństwa. Wnioskując, należy stwierdzić za Husserlem, że „wszelki pierwotny kontrast opiera się na asocjacji: niejednakowe wyodrębnia się ze wspólnego podłoża" ${ }^{\prime 2}$. Dlatego też fundamentalnymi aspektami zaistnienia genezy skojarzeniowej są homogeniczność i heterogeniczność.

We wcześniejszych rozważaniach pojawiło się określenie eksplikacji jako tendencji spostrzeżeniowej. W przebiegu tej tendencji, przynależnej do ja, dokonuje się „doksyczny zwrot-ku”, jako skierowanie przedmiotowe w postaci uwagi. Jest ona zainteresowaniem tym, czego ja chce doświadczyć w ak-

\footnotetext{
23 Tamże, s. 79.

24 Tamże, s. 79-80.

25 Tamże, s. 80.

26 Tamże, s. 81.
} 
tach intencjonalnych, wypełniając się w działaniu. W niej (w uwadze) świadomość uchwytuje jakiś byt. Charakterystyczny zwrot Husserla „doksyczny zwrot-ku" utożsamiany jest właśnie z uwagą ${ }^{27}$.

Husserl pisze:

uwaga jest [...] skłanianiem się ja do przedmiotu intencjonalnego, do jedni [...] pośród zmienności sposobów dania, a mianowicie jako skłanianie się realizujące. Realizacja zaczynająca się zwrotem-ku, [...] jest początkiem [...] skierowania ja na przedmiot. [...] I tak aż do „końca” lub przerwania [...]. Początek ma więc intencjonalny horyzont, wskazuje poza siebie w pusty, dopiero w późniejszych urzeczywistnieniach unaoczniający się sposób ${ }^{28}$.

Jeśli nie dochodzi do konkretnej realizacji poznania, jeżeli ja w przeżyciach intencjonalnych nie dąży w modus tendencji do wypełnienia naoczności intencji poprzez rozmaite sposoby dania określonego obiektu, wtedy mamy do czynienia z, jak pisze Husserl, zahamowaniem tendencji spostrzeżeniowych, jako z zaprzestaniem przez ja „czynienia” $z w r o t u-k u$. W tej sytuacji przedmiot oglądu prezentuje się poznającemu podmiotowi z danej, konkretnej strony. (Husserl w dalszej części wywodów prezentuje szereg modalizacji, jeśli idzie o przebieg tendencji (negacja, możliwość problematyczna, możliwość otwarta; w sferze predykatywnej pisze o świadomości wątpienia i możliwości).

W przypadku rozważań na temat eksplikacji, powyżej scharakteryzowane pokrótce tendencje, które ulegają zahamowaniu, nie będą miały ważącego znaczenia, gdyż odbywa się ona na wyższym piętrze dokonań konstytutywnych i stanowi głębszy wymiar aktywnego zainteresowania. Poprzedza ją proste ujęcie. Jest ono oglądem przedmiotu, będącym "punktem startowym” obiektywizującego ujęcia, posiadającym już na tym początkowym etapie wypełnieniowe antycypacje. Te antycypacje stanowią protencyjne oczekiwania co do własności oglądanego przedmiotu. W kierunku antycypowanych cech, kształtujących się na podłożu wewnętrznego horyzontu, spojrzenie niejako identyfikuje przedmiot - nie jako zupełnie mu obcy obiekt poznania, lecz jakby apriorycznie już znany, niedookreślenie sklasyfikowany. Kolejny etap zainteresowania na poziomie eksplikacyjnego oglądu stanowią już antycypacje dane w źródłowej naoczności. Eksplikację możemy zatem, za Husserlem, zdefiniować jako „wejście kierunku zainteresowania spostrzeżeniowego

\footnotetext{
27 Tamże, s. 77-89.

${ }^{28}$ Tamże, s. 85.
} 
w wewnętrzny horyzont przedmiotu" ${ }^{29}$. Idzie tu o ujęcie przedmiotu tak, jak on się jawi, jako takiego, ze spostrzeżeniową dążnością do jak najbardziej pełnego uchwycenia jego określeń, cech i momentów. Jednia przejawu danego w eksplikacyjnym oglądaniu przedmiotu stanowi substrat jego wewnętrznej, danej w syntetycznym zespoleniu, zawartości ${ }^{30}$.

Następna część moich rozważań będzie oscylowała wokół charakterystyki zarysowanej przez twórcę fenomenologii rozdziału pomiędzy eksplikacyjną syntezą a eksplikującym oglądaniem. W odniesieniu do drugiego $\mathrm{z}$ wymienionych przypadków proste oglądanie i ujmowanie nie jest dla ja zadowalające. Zainteresowanie wykazuje stopień niehamowanej analizy, jeśli idzie o spostrzeganie coraz intensywniej drążące wewnętrzną zawartość określeniową przedmiotu. „Płynące liniowo w sposób ciągły oglądanie przechodzi w [...] przyglądanie się, [...] tworząc łańcuch pojedynczych ujęć, [...], które, powiązane ze sobą, stają się politetyczną jednością łączącą poszczególne tezy"31. $\mathrm{W}$ duchu trancendentalnej fenomenologii należy sformułować wniosek, że wszystko to, co daje się w fenomenologicznej samoprezentacji źródłowo doświadczyć, co dane jest w intuicyjnym oglądzie, posiada charakterystyczny dla siebie sposób dania, właściwą tylko sobie modi prezentacji. Zarazem przynależy do niego antycypowany z góry zespół oczekiwań - wstępnie zarysowany typ przedmiotu i charakterystyczne jemu określniki, które w toku dalszej eksplikacji drogą naoczności zostaną potwierdzone lub skorygowane. Na początku eksplikacyjnej drogi, jak pisze Husserl, chodzi jednak o dostęp do czegoś, co będzie stanowiło odstąpienie od metody prostego oglądania i skieruje proces źródłowego oglądania w bardziej zaawansowaną stronę mianowicie o uchwycenie ogólnej istoty. Co fenomenolog ma na myśli, pisząc o rozwijającym oglądaniu? Niech $S$ będzie przedmiotem pewnego określonego typu, ku któremu kieruje się zainteresowanie poznającego podmiotu, $\mathrm{z}$ kolei $a, b$... stanowią jego wewnętrzne cechy i momenty.

Odbywająca się w ciągu następujących po sobie ujęć prezentująca naoczność toczyć się będzie w następujący sposób:

w całym tym procesie pojedynczych aktów prowadzących od ujęcia $S$ do ujęć a, b... poznajemy S. Proces ten jest [...] jednością rozczłonkowanego oglądania. Dzięki całemu temu procesowi $S$ zachowuje charakter tematu i gdy stopniowo uchwytujemy moment za momentem, [...] taki moment czy część to wła-

\footnotetext{
29 Tamże, s. 107.

30 Tamże, s. 89-95, 105-106.

31 Tamże, s. 114.
} 
sność, określenie; nie jest to nic dla siebie, lecz coś od przedmiotu S, coś z niego i w nim. Nieokreślony temat $S$ staje się w tym rozwinięciu substratem własności, jakie wystąpiły, one same zaś konstytuują się w czasie jako jego określenia ${ }^{32}$.

Najprościej ujmując - proces poznania S w szeregu następujących po sobie ujęć jego eksplikatów nie stanowi prostej ich sumy. Świadczyć mogłoby to o wzajemnym braku powiązania i odrębności tematycznej. Raczej kolejne ujęcia przylegają do $S$ w drodze zapadającego w retencjonalną świadomość osadu (w innym miejscu Husserl pisze o habitualnym zasobie, który nie znika, lecz stanowi bazę dla asocjacyjnych przebiegów świadomości) ${ }^{33}$.

Interesujące staje się pytanie, jak to się dzieje, że $S$ wykazuje stały charakter substratu, natomiast przynależne do niego eksplikaty występują w odmiennej roli i wykazują utrzymujący się sens jego określników? Bo przecież nasz przedmiot dany originaliter jest definiowany w kategoriach $a, b, c \ldots$ i pojmowany jako główny temat, górujący nad rozczłonkowanymi tematycznie, intuicyjnie odsłaniającymi się własnościami. Decydujące o tym intencjonalne przebiegi świadomości motywują powiązania, doprowadzające do uświadomienia sobie przez poznający podmiot, że dążąc do osłonięcia w źródłowej naoczności zarysowanego typu określników, w istocie ma do czynienia z poznaniem $S$. Taki rodzaj uświadomienia jest niezbędny dla zaistnienia prawidłowego przebiegu eksplikacji, która ma na celu - na drodze ukazywania się dualistycznie pojmowanego sensu (rozpoznania przedmiotu jako substratu oraz jego eksplikatów) - uwyraźnienie drogą bezpośredniego oglądu ukazującego się strukturalnie przedmiotu. Te dwa konteksty sensu „zlewają się” ze sobą w formie jedni pokrycia ${ }^{34}$.

Przejdę teraz do opisu eksplikacyjnej syntezy pokrycia, jako syntezy nakładania się. Jak pisze Husserl, „przy przejściu od ujęcia 'S' do ujęcia 'a' uderza pewne duchowe nakładanie się. Powstaje zarówno wtedy, gdy jakaś rzecz jest zrazu ujmowana w niepodzielnej jedności, [...] jak i wtedy, gdy syntetycznie ujmuje się najpierw pewną rzecz, a potem osobno i nie jako jej określenia pewien kształt, pewne brzmienie i pewną won'" ${ }^{35}$. W przypadku takiej syntezy nakładania się, ja musi wykazywać się permanentną aktywnością. Każde ujęcie jest niejako zatrzymywane i nie traci na ważności; z kolei nowe ujęcie nie jest w stanie całkowicie zdominować tego, które je poprzedza - czynne ja

\footnotetext{
32 Tamże, s. 115.

33 Tamże, s. 114-122.

${ }^{34}$ Tamże, s. 115.

35 Tamże, s. 116.
} 
poprzez nowe uchwycenie zwraca się w stronę minionego. Ja nie faworyzuje „świeżego" ujęcia, lecz otwiera się aktywnie jedno na drugie, a promieniowanie rozgałęzia się zarówno na promieniowanie uwagi, jak i na promieniowanie ujęcia. Zważyć należy przy tym, czy w trakcie eksplikacyjnego oglądu i pokrycia zachodzi synteza tożsamości, i czy cały proces odbywa się zgodnie $\mathrm{z}$ przedmiotowym sensem. Idzie tutaj o syntezę tożsamości osobliwego rodzaju - tożsamości przedmiotu będącego substratem - jako podłożem danych w uwyraźniającej naoczności eksplikatów, oraz tychże eksplikatów. „Tego, [...], eksplikacyjnego pokrycia nie można mieszać z zupełnym pokrywaniem się tożsamości w zakresie przedmiotowego sensu [...]"36. To drugie odnosi się do formy przedstawieniowej. Pokrywanie się tożsamości, które zwrotnie identyfikuje przedmiot $\mathrm{z}$ sobą samym, występuje $\mathrm{w}$ ciągu zmieniających się przedstawień i różnic $\mathrm{w}$ jego naocznościowym charakterze prezentowania się. W przypadku eksplikacyjnego pokrycia mamy przed sobą tożsamość innego rodzaju. Odnosi się ono ściśle do substratu i jego określeń. Są one „źródłowo konstytuowane [...] jako skorelowane człony pewnego rodzaju pokrywania się" ${ }^{\prime 3}$. Dany eksplikat, przewrotnie, zarówno jest naszym substratem, jak i nim nie jest... Zupełnie zrozumiałe staje się wówczas określenie Husserla, że eksplikacyjne pokrycie (poprzez toczącą się identyfikację) odznacza się „osobliwą dyskretnością". Wszak całość poznania przez nas rzeczywistości i epistemiczna jej osiągalność to jedna wielka tajemnica...

\section{Podsumowanie}

Powyższe rozważania dotyczyły metody eksplikacyjnego oglądu jako otwierającej drogę do uwydatnienia jakości, jakimi dysponuje każdorazowy przedmiot naszego poznania. Za punkt wyjścia obrałam rozważania odnoszące się do kategorii intuicji rozumianej jako bezpośredni ogląd przedmiotu. W powiązaniu z zagadnieniem eksplikacji starałam się w pełni oddać charakter i naświetlić dewizę przewodnią, jaka przyświecała Husserlowi jako twórcy metody transcendentalnej fenomenologii, zawartej w hasłach Wesenchau, czy Zurück zu den Sachen! i którą wyrażonej w zasadzie wszystkich zasad, która brzmi: „Każda źródłowo prezentująca naoczność jest źródłem prawomoc-

\footnotetext{
36 Tamże, s. 117.

37 Tamże.
} 
ności poznania, że wszystko, co się nam w «intuicji» źródłowo przedstawia, należy po prostu przyjąć jako to, co się prezentuje, ale także jedynie w tych granicach, w jakich się prezentuje" ${ }^{38}$. W każdej źródłowo prezentującej naoczności mamy dążyć do jak najbardziej rzetelnego poznania przedmiotu, do jak najwyraźniejszego ujęcia jego cech. Musi się ono opierać na czystej, „poredukcyjnej” świadomości. Dzięki spełnieniu tych warunków, eksplikacja ma szansę prawomocnego przebiegu - jako wyższy stopień oglądu danego originaliter przedmiotu. W tym aspekcie Husserl dotyka także kategorii eksplikacji w Medytacjach kartezjańskich (może nie tak szczegółowo jak w Doświadczeniu i sądzie) i ujmuje ją raczej w ramach ontologicznych, wiążąc z podstawowymi zagadnieniami fenomenologii transcendentalnej (materialne a priori, redukcja transcendentalna, nastawienie ejdetyczne, problematyka konstytucji).

Nasze wywody wypada zakończyć słowami samego mistrza, że w tym wszystkim przecież chodzi o

świat, w którym my, ludzie, żyjemy, [...], byśmy zaczynali [...] od przebadania, właśnie w czystej intuicji, niezwykle bogatego i nigdy dotąd nie ujawnionego a priori, które leży u podstaw tego świata otaczającego jako takiego, jak również od obrania tego a priori za punkt wyjścia dla systematycznego rozwijania struktur określających istotę egzystencji (Daseins) ludzkiej [... $]^{39}$.

Człowiek i świat to w końcu dwa przeciwległe sobie bieguny, którym fenomenologia daje szansę się odsłonić i choć trochę poznać.

\section{Bibliografia}

Husserl E., Badania logiczne, przeł. J. Sidorek t. 2, cz. II, PWN, Warszawa 2000.

Husserl E. Doświadczenie i sąd, przeł. B. Baran, Fundacja Aletheia, Warszawa 2013. Husserl E., Idee czystej fenomenologii i fenomenologicznej filozofii, Księga I, przeł. D. Gierulanka, PWN, Warszawa 1975.

Husserl. E., Medytacje kartezjańskie, przeł. J. Sidorek, PWN, Warszawa 1982.

${ }^{38}$ E. Husserl, Idee czystej fenomenologii i fenomenologicznej filozofii, Księga pierwsza, tłum.

D. Gierulanka, Warszawa 1975, s. 73.

${ }^{39}$ E. Husserl, Medytacje kartezjańskie, s. 207. 
Łukasiewicz D., Sad i poznanie w fenomenologii Edmunda Husserla, Wydawnictwo Rolewski, Bydgoszcz 2008.

Półtawski A., Świat. Spostrzeżenie. Świadomość. Fenomenologiczna koncepcja świadomości a realizm, PWN, Warszawa 1973.

\author{
Abstract \\ Husserl's Explication as a Higher Form of the Intuition-Based Method \\ of the Phenomenological View
}

The article presents Husserl's issues of explication. These issues take place on the higher level of constitutive accomplishments. Precise characterization of these issues was undertaken by Husserl in his work „Experience and Judgement”. This article begins with the consideration of the category of intuition as the experience of the object available to subject due to the originally presentive consciousness. The next part of this work concentrates on the analysis of explication as the deeper form of original experience.

Key words: explication, intuition, intention, constitution, synthesis 